Laczó, Ferenc. "Köbányai, János, ed. 2017. Holokauszt-olvasókönyv ['Holocaust Reader']. Budapest: Múlt és Jövő. 792 pp." Hungarian Cultural Studies. e-Journal of the American Hungarian Educators Association, Volume 11 (2018) DOI: 10.5195/ahea.2018.338

\title{
Köbányai, János, ed. 2017. Holokauszt-olvasókönyv ['Holocaust Reader']. Budapest: Múlt és Jövő. 792 pp.
}

\author{
Reviewed by Ferenc Laczó ${ }^{1 *}$, Maastricht University
}

Between 1911 and 1944 Hungarian-Jewish writer, translator and folklorist József Patai founded and regularly published the Jewish cultural journal Múlt és Jövő ['Past and Future']. Having disappeared for nearly half a century, the journal was - after being preceded by a 1988 anthology - re-launched in 1989 and in 1994 joined by an identically named publishing house. According to its website the new Múlt és Jövö represents "a cause and a tradition: the practice and popularization of Hungarian Jewish culture and the preservation of its memory - with our 'protective eyes' on Jerusalem and modern Israel" (www.multesjovo.hu). Managed and intellectually directed by the prolific writer János Kőbányai, Múlt és Jövő amounts to the largest explicitly Jewish publishing house and intellectual journal of post-communist Hungary: by late 2017, the publishing house has released an impressive number of two hundred and seventeen volumes, most - though far from all - of which are reprints, while the journal has a hundred and seven issues to its credit.

It therefore qualifies as a significant event that in 2017 János Köbányai decided to publish a large reader devoted to the Holocaust and containing almost seventy texts on this topic that were published by the journal over the past nearly three decades. Next to the Foreword by the editor, the volume's sixty-nine articles are approximately equally divided into scholarly studies and opinion essays or personal recollections. Holokauszt-olvasókönyv features sixty-one authors, only two-thirds of whom are still alive. There is a considerable gender imbalance among the authors as three-quarters of them are male. About half of the sixty-one authors are Hungarian, another seven qualify as minority Hungarians from across Hungary's borders, while another ten have emigrated from the country - half of them to Israel and the other half further to the West. Consequently, there are only four Americans who do not originate from Hungary (including historian Randolph L. Braham, who grew up in Romania) and no more than five nonHungarian Europeans (including some of the most famous intellectuals, politicians and religious leaders, such as Václav Havel, Jacques Chirac or Pope John Paul II). In other words, neither the broader and eminently multilingual European discussions of the Holocaust, nor the specificities of the East-Central European region beyond the case of Hungary receives extended attention in the volume. (The number of translations from various languages only reinforces this impression: English with nine is the clear number one here with Hebrew being the sole other language from

*f.laczo@maastrichtuniversity.nl

$($ (c) $)$ EY

ULIS D-Sente
New articles in this journal are licensed under a Creative Commons Attribution 4.0 International License.

This journal is published by the University Library System of the University of Pittsburgh as part of its D-Scribe Digital Publishing Program and is cosponsored by the University of Pittsburgh Press 
Laczó, Ferenc. "Köbányai, János, ed. 2017. Holokauszt-olvasókönyv ['Holocaust Reader']. Budapest: Múlt és Jövő. 792 pp." Hungarian Cultural Studies. e-Journal of the American Hungarian Educators Association, Volume 11 (2018) DOI: 10.5195/ahea.2018.338

which more than one translation got included.) In sum, without making this explicit in its title, Holokauszt-olvasókönyv essentially remains a reader of Hungarian Jewish discussions regarding the Holocaust.

While not quite all the contributors may be Jewish, this very much remains a reader defined primarily by those who had to experience the Holocaust in their youth and those born shortly afterwards - some are survivors, others researchers, and many of them both. A tiny majority of thirty-one contributors out of the sixty-one were born between 1920 and 1939 and seventeen additional authors were born in the 1940s or 1950s, with the youngest one of them all having been born in 1973. Besides notable American and Israeli authors such as Randolph Braham, Leora Bilsky, Ilana Rosen or Sidra DeKoven Ezrahi, the book features a host of outstanding Hungarian Jewish authors from various disciplines, such as Ágnes Heller, György Konrád, Ferenc Erös, Rudolf Klein, György Haraszti, János Pelle, Júlia Vajda, Andrea Dunai, or the late Mária Ember and Teréz Virág. In terms of the years of original release, the most common years are 2004, the sixtieth anniversary of the Holocaust in Hungary (eight of the texts reprinted here were published then), followed by 1992, 1994 and 2009 (all three with six texts altogether) and then by 1990, 1991 and 2000 (all three with four texts altogether). In other words, next to round anniversaries, most of the peak years belong to the early 1990s, arguably the most innovative and exciting period of the then renewed journal.

"Megtörni a hallgatást" ('Breaking the Silence,' 37-46) by Ferenc Erős from the 1988 Múlt és Jövö anthology belongs among the most important early contributions. Erös addresses the basic question in psychiatry and psychosociology regarding the long-term consequences of the Holocaust for its survivors and their descendents in those years. He argues that silencing the traumatic experiences only makes the process of inheritance more burdensome as it helps "reproduce psychopathological mechanisms" and it even "additionally creates a row of fake situations" (45). By contrast to these harmful mechanisms, Erős contends, it is possible to channel the traumatic experience into an engagement with the meaning of survival and all that the survivors have learned and can pass on to their offspring about their life experiences. Equally importantly, Erős's article tells us that even those survivors who live with their descendents in Western societies and appear perfectly socially integrated face psychic problems, whereas on his side of the Iron Curtain such phenomena have barely come to be known and explored. Erös concludes his article claiming that studying the broader societal environment is crucial in determining whether the preconditions of breaking the silence would be met.

The volume's Foreword by Editor János Köbányai declares Múlt és Jövö to be "the forum of the victim people and their culture" (11) and asserts that the work of mourning could eventually result in catharsis. Köbányai cites Imre Kertész's hope that the Holocaust may create a new culture and become a precious source of future moral reserve. Köbányai maintains, however, that in present-day Hungary the key cultural role of the Holocaust works in the exact opposite manner. He deplores that the absence of an earnest engagement with Holocaust history continues to define the "bad (even sick)" atmosphere of the country and is also responsible for "the low quality of Hungarian public discourse" as such (14).

In his closing "A magyar arkangyal azt üzente..." ('Thus spoke The Hungarian archangel..., 761-766), Köbányai underlines the primacy of Hungarian responsibility for the Hungarian chapter of the genocide of European Jews and aims to inquire how Hungarian society has come to deal with its responsibility. He arrives at the slightly provocative conclusion that the 
Laczó, Ferenc. "Köbányai, János, ed. 2017. Holokauszt-olvasókönyv ['Holocaust Reader']. Budapest: Múlt és Jövő. 792 pp." Hungarian Cultural Studies. e-Journal of the American Hungarian Educators Association, Volume 11 (2018) DOI: 10.5195/ahea.2018.338

German Occupation Memorial erected in the middle of a 2014 summer night adequately reflects the mainstream practices of denial, self-defense and rejection, and he claims that the perpetrators and the memory of their deeds remain non-issues in Hungary. Köbányai adds with a resigned voice that repression and silencing have become an established practice which it would be too late to try to alter now. He concludes with a radical adaptation of Ralph Giordano's thesis on German society's second guilt, asserting that the fact that even the intention to confront Hungarian guilt has remained practically absent is "even more painful than what was committed" (766).

Ágnes Heller's reflections titled "A holokauszt és a nemzedékek" ('The Holocaust and the Generations,' 17-27) begin with a clarification that the essence of the Holocaust is senseless and unbearable suffering, and the majority of the varied acts of its remembrance are to be qualified as inauthentic as they merely concern "fictions of the Holocaust" (17). By contrast to these, Heller argues, authentic remembrance would have to be unbearable and that presupposes inducing the experience of simultaneity as known from Jewish tradition. In this manner, she takes a clear stance against attempts to historicize the Holocaust. Somewhat incongruously to her preceding discussion of fictional as opposed to authentic Holocaust remembrance, Heller then presents what she considers to be the three main stages of remembering the Holocaust: silencing, rediscovery and general discourse. She concludes that the fundamental trend is increased identification with the victims. She asserts that such acts of assuming roles, i.e. of emotionally and morally connecting to the unbearable suffering of the victims, contain the seeds of catharsis. Heller also believes in the possibility of taking responsibility if the Holocaust was going to be remembered as a crime that we as present-day individuals did not commit but that, frighteningly, we as humans are capable of committing.

While the volume contains many more valuable contributions, the four contributions by three authors highlighted above suggest a main narrative arc of how the call of the late 1980s to become conscious of traumatization and start dealing with its long-term consequences (made, among others, by Ferenc Erös) was soon followed by attempts to pursue the work of mourning and by explicit demands for public recognition of Hungarian responsibility (made, rather forcefully, by János Köbányai) as well as by intriguing reflections on how to maintain the cultural significance of the Holocaust without essentializing ethnic identities (as developed, for instance, by Ágnes Heller).

Concurring with the latter perspective, Júlia Vajda argues in her "Emlékezés a Gonoszra" ('Remembering Evil,' 467-476) that what Hungarian society needs are not conventional memorials but Mahnmale, memorials that admonish, emphatically warn and urge, and thereby make sure that the Holocaust in Hungary becomes more than an exclusive matter for survivors and their descendants. In sum, the present Holocaust Reader compiled by János Köbányai articulates notable Jewish perspectives on the Holocaust in Hungarian culture and also excels at showing why these reflections ought to matter beyond the admittedly somewhat narrow circles of those explicitly concerned about such perspectives. 